NSF: $\quad 1988$

PT 34

LOC 0102000

KW 1002009

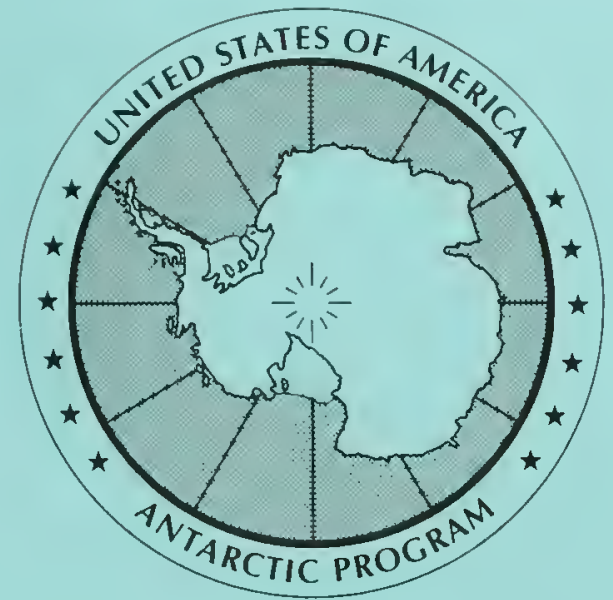

WORKSHOP ON

\title{
ULTRAVIOLET RADIATION AND
}

\section{BIOLOGICAL RESEARCH IN}

ANTARCTICA

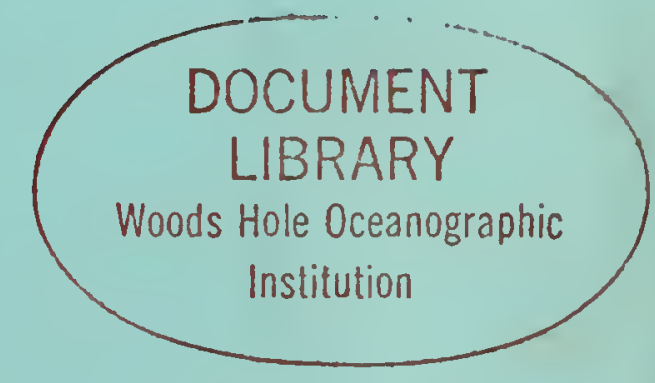

June $7-8,1988$

QP

82.2

.114

126

1988
National Science Foundation 1800 G St. N.W., Washington, D.C. 
The National Science Foundation has TDD (Telephonic Device for the Deaf) capability, which enables individuals with hearing impairment to communicate with the Division of Personnel and Management about NSF programs, employment, or general information. This number is (202) 357-7492.

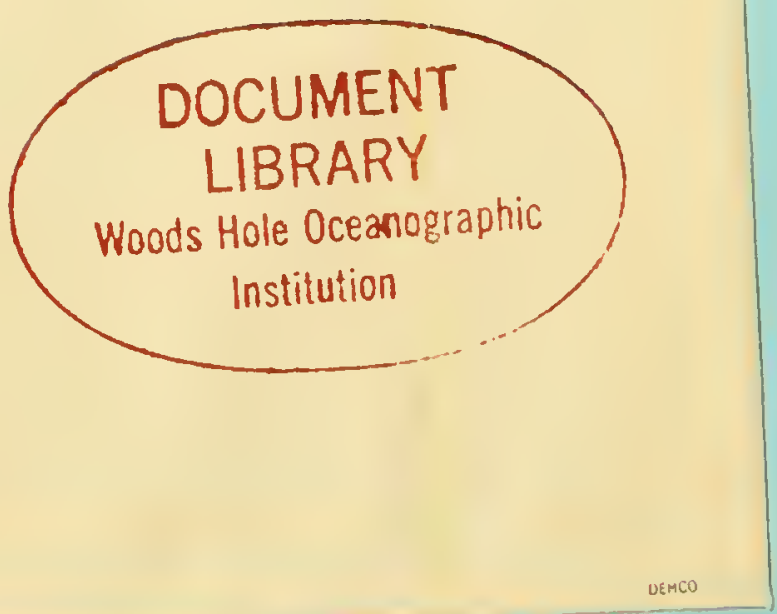




\title{
WORKSHOP ON \\ ULTRAVIOLET RADIATION AND \\ BIOLOGICAL RESEARCH IN ANTARCTICA
}

\author{
June 7-8, 1988 \\ National Science Foundation \\ 1800 G St. N.W., Washington, D.C. \\ CO-SPONSORED BY: \\ Division of Polar Programs \\ National Science Foundation \\ and \\ United States Environmental Protection Agency \\ Environmental Research Laboratory-Corvall is
}

ORGANIZED AND EDITED BY:

C.S. Weiler

Division of Polar Programs

National Science Foundation

Washington, D.C. 20550 



\title{
INTRODUCTION
}

\author{
C. SUSAN WEILER \\ Division of Polar Programs \\ National Science Foundation \\ 1800 G St. NW \\ Washington, D.C. 20550
}

WORKSHOP GOALS:

Over the past 10 years, ozone values over the Antarctic continent have dropped dramatically during the austral spring. Because ozone absorbs strongly in the UV-B (280-320 nm) portion of the solar spectrum and because UV-B radiation is known to be injurious to life, it is important to assess the biological consequences of enhanced UV-B radiation resulting from stratospheric ozone depletion. In order to inform and educate the scientific community about Antarctic UV research, the National Science Foundation's Division of Polar Programs and the United States Environmental Protection Agency's Environmental Research Laboratory in Corvallis, Oregon co-sponsored a workshop on ultraviolet radiation and biological research in Antarctica. The workshop was held in Washington, D.C. on June 7-8, 1988.

The goals of the workshop were to: provide an overview of UV-B effects on organisms and UV radiation measurements for individuals interested in conducting research on the consequences of enhanced UV-B radiation for Antarctic organisms and personnel; describe the network the United States Antarctic Program is developing for monitoring ultraviolet radiation; and provide a forum for discussions among researchers interested in conducting UV research in Antarctica and established UV researchers.

The workshop began with presentations on the status of present knowledge concerning biological UV effects. The presentations were followed by discussions on the United States Antarctic Program's UV radiation monitoring equipment (led by G.W. Harris) and UV monitoring program (led by C.R. Booth), and a tutorial and discussion on UV lights, filters, and measurements for use in biological research (led by M.M. Caldwell). Fifty one scientists from Australia, Chile, Argentina, and a variety of U.S. research institutions and federal agencies participated in the workshop, which was attended by over 70 individuals.

To stimulate greater community awareness and provide an introduction to the field of UV effects on organisms, NSF has compiled this summary of the workshop presentations; an abstract and short list of key references from each talk is provided.

ULTRAVIOLET RADIATION MONITORING PROGRAM:

While it is known that decreases in total ozone will increase the amount of UV- $B$ radiation reaching the earth's surface, models have not yet been developed that can accurately predict ultraviolet radiation levels at the earth's surface for high latitudes. In order to obtain direct measurements of predicted changes in uitraviolet radiation levels resulting from the Antarctic "ozone hole", the United States Antarctic Program (USAP) is developing a network for monitoring ultraviolet radiation. Equipment systems have been installed at three Antarctic 
locations (South Pole, McMurdo, and Palmer Stations), and a system is planned for installation at Ushuaia, Argentina. Data from this network will be used to determine the extent of ultraviolet radiation enhancement due to Antarctic ozone depletion and to estimate the health and biological consequences of stratospheric ozone depletion for Antarctic organisms and personnel.

\section{WORKSHOP SUMMARY:}

Because so little biological UV research has been conducted in Antarctica, workshop speakers reviewed research results from lower latitudes. Where possible, speakers and participants commented on the implications of UV trends for Antarctic organisms; these insights are summarized below.

Both Martyn Caldwell and Richard Setlow stressed that there are considerable gaps in our knowledge of UV effects on organisms (and Antarctic organisms are virtually unstudied at this time). Caldwell established the importance of obtaining accurate and biologically relevant action spectra for UV damage. He pointed out that different cellular processes have different action spectra and that ozone reduction causes damage for a particular system or organism only if the relevant biological action spectrum/spectra has certain characteristics, such as increasing detrimental effect with decreasing wavelength over the ozoneabsorbing (UV-B) region. In addition to obtaining accurate dose-response curves, Setlow urged Antarctic researchers to establish the relationship between UV dose, dose rate, and biological effect.

Arlin Krueger noted that in October 1987, ozone values in some areas were close to zero at the altitude where the ozone maximum usually occurred. This implies column ozone may not fall much below the 1987 ozone minimum (109 DU) unless it is removed from other altitudes. Krueger and John Frederick pointed out that solar elevation has a strong effect on UV-B penetration; solar elevation at midday increases between June 21 and Dec. 21, and toward the equator. Therefore, even if ozone levels are the same or higher than the October 1987 ozone minimum values, increases in the size of the ozone hole or in its duration will significantly increase the amount of UV-B penetrating to the earth's surface. Because UV penetration varies so strongly with latitude, maximum UV penetration in the Antarctic will not necessarily coincide with the ozone minimum. Because photoperiod changes rapidly and dramatically between June and December in Antarctica, it will be important to monitor organism responses to both the maximum daily UV-B dose and the integrated daily UV-B dose. Frederick's model calculations indicate that UV-B levels for the ozone minimum (October 5) were comparable to summer solstice values at that location; Antarctic organisms presumably have not experienced "record" UV-B levels, though spring UV-B levels were higher than normal.

Data on the motion of the ozone hole show changes in the position of the hole relative to geographical locations. In a matter of days, a particular region may experience dramatic changes in UV-B radiation (column ozone changes of more than 150 DU have already been observed over this time scale). Ray Smith coined the term "Middle-UV front" for this phenomenon. Because it is so difficult to reconstruct the solar UV-B spectrum with artificial light sources, the UV front provides a unique opportunity to study the response of organisms to large changes in solar UV-B. Smith noted that organisms adapted to gradual seasonal changes in UV-B may not be able to respond equivalently to similar or greater changes 
condensed over a short period.

Bruce Chalker noted that many tropical organisms protect themselves from UV-B with mycosporine-like amino acids which absorb strongly in the UV-B region. Chalker urged that Antarctic organisms be tested for the presence of UV-absorbing compounds. Because organisms may synthesize UV-absorbing compounds only when needed, he suggested that organisms be preconditioned on ecologically appropriate time scales when conducting UV-enhancement experiments.

Frederick's calculations indicate that UV-B levels over Antarctica have not yet exceeded those in the United States; Antarctic personnel are therefore not presently at particular risk. The United States Antarctic Program will monitor UV radiation beginning in 1988, and a panel of experts will be assembled to evaluate the health and biological consequences of the data. Hugh Taylor advised that Antarctic personnel obtain and use sunglasses coated with a compound that absorbs $100 \%$ of wavelengths below $400 \mathrm{~nm}$. Because sunglasses are not uniformly labelled, he urged that sunglasses be purchased from a knowledgeable source such as an optometrist.

Caldwell led a tutorial and discussion on UV lights, filters, and measurements for use in biological research. His presentation drew on the following reference: Caldwell, M.M., W.G. Gold, G. Harris and C.W. Ashurst, 1983; A modulated lamp system for solar UV-B (280-320 nm) supplementation studies in the field (Photochem. Photobiol. 37: 479-485). Caldwell stressed that it is exceedingly difficult to mimic solar UV with artificial light sources and to accurately measure UV dose. To ensure meaningful and reproducible results, an experienced photobiologist should be consulted before conducting UV research. Participants agreed that efforts should be made to establish a standard protocol for UV lights, filters and measurements; lack of standardization has made it difficult and sometimes impossible to compare results from different studies.

Participants agreed that the first priority for Antarctic biological UV research should be to evaluate the consequences of enhanced UV-B for marine phytoplankton, since the marine ecosystem accounts for most Antarctic production and phytoplankton form the base of the marine food chain. Because water movements prevent long-term monitoring of the same water mass, another priority should be the establishment of terrestrial plots to monitor the effect of UV-B changes within and between years.

Participants concurred that it is essential to monitor Antarctic UV-B radiation with wavelength-specific equipment and applauded the United States Antarctic Program for establishing a UV monitoring network. They also unanimously agreed that a similar program should be instituted for monitoring UV radiation within the United States and in other countries. NOAA has been monitoring UV radiation with Robertson-Berger meters since 1974. Participants agreed that these sensors, which integrate dose over 290-330 nm and are biased towards wavelengths which are not strongly absorbed by ozone, should be replaced with spectroradiometers such as those used for the United States Antarctic Program. Participants urged that the Robertson-Berger network be continued until new and better equipment is in place. 


\title{
* SOLAR UV AND THE ROLE OF ACTION SPECTRA IN ASSESSING THE BIOLOGICAL CONSEQUENCES OF SOLAR UV-B RADIATION
}

\author{
MARTYN M. CALDWELL \\ Department of Range Science \\ Utah State University \\ Logan, UT 84322-5230
}

\begin{abstract}
*Abstract taken from Caldwe11, M.M., L.B. Camp, C.W. Warner, and S.D. Flint, 1986. Action spectra and their key role in assessing biological consequences of solar UV-B radiation change. In, NATO ASI Series, Vol. G8: Stratospheric Ozone Reduction, Solar U7traviolet Radiation and Plant Life (R.C. Worrest and M.M. Caldwe11, eds.). Springer-Verlag, Berlin, pp. 87-111.
\end{abstract}

ABSTRACT: Action spectra of UV damage to plants must be used as weighing functions to (1) evaluate the relative increase of solar UV radiation that would result from a decreased atmospheric ozone layer, the radiation amplification factor--RAF, (2) evaluate the existing natural gradients of solar UV irradiance on the earth, and (3) compare UV radiation from lamp systems in experiments with solar UV radiation in nature. Only if the relevant biological action spectra have certain characteristics is there a potential biological problem that would result from ozone reduction. Similarly the existence of a natural latitudinal solar UV gradient is dependent on action spectrum characteristics.

Several UV action spectra associated with different basic modes of damage to plant tissues all have the common characteristic of decreasing effect with increasing wavelength; however, the rate of decline varies considerably. Extrapolation from action spectra that have been measured on isolated organelles and microorganisms using monochromatic radiation to effects of polychromatic radiation on intact higher $\mathrm{plants}$ is precarious. Development of action spectra using polychromatic radiation and intact higher plant organs can yield spectra that are of more ecological relevance for weighing factors in assessment of the ozone reduction problem. An example of an action spectrum for photosynthetic inhibition developed with polychromatic radiation is provided in this chapter. This action spectrum has different characteristics, and results in a greater RAF than do action spectra for inhibition of a partial photosynthetic reaction, the hill reaction, developed with isolated chloroplast and photosynthetic bacteria. Circumstantial evidence from experiments with plants originating from different latitude also supports the notion that action spectra with characteristics similar to that of the provisional spectrum, developed with polychromatic radiation, are appropriate. Further work with polychromatic radiation is encouraged.

There are two basic types of error that are associated with the use of action spectra in biological assessments of the ozone reduction problem, the RAF errors and the enhancement errors. The former are those associated with calculation of the RAF, and the latter are those derived from calculation of the UV radiation enhancement used in experiments with lamp systems. While the RAF errors are recognized, the enhancement errors have not been generally appreciated. An error analys is is presented showing that the enhancement errors will typically be larger and in the opposite direction than the RAF errors. The enhancement error 
should be considerably less in field UV supplementation experiments than in most laboratory experiments which employ fluorescent lamps as the primary UV-B radiation source.

\section{REFERENCES:}

Caldwe11, M.M., 1981. Plant response to solar ultraviolet radiation. In, Encyclopedia of Plant Physiology, vol. 12A, Physiological Plant Ecology. I. Responses to the Physical Environment (0.L. Lange, P.S. Nobel, C.B. Osmond, and H. Ziegler, eds.). Springer, New York, $169 \mathrm{pp}$.

Caldwell, M.M., L.B. Camp, C.W. Warner, and S.D. Flint, 1986. Action spectra and their key role in assessing biological consequences of solar UV-B radiation change. In, NATO ASI Series, Vol. 8: Stratospheric Ozone Reduction, Solar Ultraviolet Radiation and Plant Life (R.C. Worrest and M.M. Caldwell, eds.). Springer-Verlag, Berlin, pp. 87-111.

Caldwe11, M.M., W.G. Gold, G. Harris and C.W. Ashurst, 1983. A modulated lamp system for solar UV-B (280-320 nm) supplementation studies in the field. Photochem. Photobiol. 37: 479-485.

Caldwell, M.M., R. Robberecht, and W.D. Billings, 1980. A steep latitudinal gradient of solar ultraviolet-B radiation in the arctic-alpine life zone. Ecology 61: 600-611.

Natchwey, D.S., and R.D. Runde1, 1982. Ozone change: biological effects. In, Stratospheric Ozone and Man (F.A. Bower and R.B. Ward, eds.). CRC Press, Boca Raton, $81 \mathrm{pp}$.

Rundel, R.D., 1983. Action spectra and estimation of biologically effective UV radiation. Physiol. Plant. 58: 360-366.

Setlow, R.B., 1974. The wavelengths in sunlight effective in producing skin cancer: a theoretical analysis. Proc. Nat1. Acad. Sci. USA 71: 3363-3366. 


\title{
UV PHOTOBIOLOGY AND REPAIR MECHANISMS
}

\author{
RICHARD B. SETLOW \\ Biology Department \\ Brookhaven National Laboratory \\ Upton, NY 11973
}

\begin{abstract}
The ultraviolet component of sunlight is the most potent environmental agent that alters the structures of macromolecules. It has played an important role in evolution and is responsible for a wide variety of biological effects, such as inhibition of macromolecular synthesis, mutation of cells, killing of cells, as well as deleterious effects on proteins and membranes. The effects on DNA are probably the most important not only because DNA contains the information in cells necessary for transcription and translation, but because DNA is the largest molecule in cells and it has a significant absorption coefficient in the UV-B region. In this region, the sensitivity of DNA is at least 10-fold greater than that of other cellular structures.
\end{abstract}

All biological systems have developed a number of strategies for minimizing the effects of solar UV. DNA repair mechanisms presumably arose from the evolutionary pressure of ultraviolet radiation and ameliorate a large fraction of the ultraviolet effects. Two well-studied strategies are enzymatic photoreactivation (the direct reversal of UV-induced pyrimidine dimers in DNA) and nucleotide excision (the removal of photo-products from DNA by a cut and patch mechanism operating in the dark). Exposure to sunlight involves the simultaneous application of UV and photoreactivating illumination. Examples of the combined effect of this type of treatment will be given.

An understanding of the effects of the range of wavelengths present in sunlight on aquatic and terrestrial ecosystems requires a knowiedge of these effects on representative components of the systems and a basic understanding of the causes for such effects. From a photobiological point of view, the quantitative answers to the following four questions are essential:

1. What are the dose-response relations for monochromatic wavelengths?

2. Do low intensities for a long time give the same result as high intensities for a short time? (Does reciprocity hold?)

3. What is the relative effectiveness of different monochromatic wavelengths in producing the observed effect (the action spectrum)?

4. Is the sum of the effects of monochromatic wavelengths additive, antagonistic, or synergistic?

Examples of answers to these questions, and the interpretation of the answers, will be given for some well studied simple bacterial systems.

The data to be discussed are derived from the references that follow.

This work was supported by the Office of Health and Environmental Research of the U.S. Department of Energy. 


\section{REFERENCES:}

Brown, M.S. and R.B. Webb, 1972. Photoreactivation of $365 \mathrm{~nm}$ inactivation of Escherichia coli. Mutat. Res. 15: 348-352.

Freeman, S.E., A.D. Blackett, D.C. Monteleo, R.B. Setlow, and B.M. Sutherland, 1986. Quantitation of radiation-induced, chemical-induced, or enzyme-induced single-strand breaks in nonradioactive DNA by alkaline gel electrophoresis: application to pyrimidine dimers. Analyt. Biochem. 158: 119-129.

Harm, W., 1980. Biological Effects of Ultraviolet Radiation. Cambridge Univ. Press, New York, $216 \mathrm{pp}$.

Jagger, J., 1985. Solar-UV Actions on Living Cells. Praeger, New York, 202 pp.

NRC, 1982. Causes and Effects of Stratospheric Ozone Reduction: An Update. National Academy Press, Washington, pp 37-74.

Peak, M.J., J.G. Peak, M.P. Moehring and R.B. Webb, 1984. Ultraviolet action spectra for DNA dimer induction, lethality, and mutagenes is in Escherichia coli with emphasis on the UV-B region. Photochem. Photobiol. 40: 613-620.

Setlow, R.B., 1974. The wavelengths in sunlight effective in producing skin cancer: a theoretical analysis. Proc. Nat1. Acad. Sci. USA 71: 3363-3366.

Shima, A. and R.B. Setlow, 1984. Survival and pyrimidine dimers in cultured fish cells exposed to concurrent sun lamp ultraviolet and photoreactivating radiations. Photochem. Photobiol. 39: 49-56.

Tyrrel1, R.M., P. Werfelli and E.C. Moraes, 1984. Lethal action of ultraviolet and visible (blue-violet) radiations at defined wavelengths on human lymphoblastoid cells: action spectra and interaction sites. Photochem.

Photobiol. 39: 183-189. 


\title{
UV RADIATION AND THE AQUATIC ENVIRONMENT
}

\author{
RAYMOND C. SMITH \\ Center for Remote Sensing and Environmental Optics \\ University of California \\ Santa Barbara, CA 93106
}

\begin{abstract}
The work of numerous investigators provides conclusive evidence that exposure to Middle Ultraviolet (MUV) Radiation decreases algal productivity. Indeed, there is convincing evidence that MUV radiation, at present levels incident at the surface of the ocean, has an influence on phytoplankton as currently measured by fixed bottle 14 -C productivity incubations. These results suggest, but cannot prove, that ozone reduction may be harmful to phytoplankton populations in Antarctic waters. The ozone reduction over Antarctic waters during the Austral spring is now so large that it may be possible to carry out a definite experiment and provide a direct quantitative assessment of enhanced MUV on Antarctic phytoplankton populations. Data on motion of the ozone hole show that there is substantial motion of the position of the hole relative to geographical locations. The strong gradient in ozone, which characterizes the ozone hole, causes a corresponding strong gradient in MUV; i.e., a "front" of MUV. This front, analogous to oceanographic fronts, provides the opportunity to carry out experiments on either side of the front and to compare the influence of change in MUV stress in mature phytoplankton populations.
\end{abstract}

\section{REFERENCES:}

Baker, K.S. and R.C. Smith, 1982. Spectral irradiance penetration in natural waters. In, The Role of Solar Ultraviolet Radiation in Marine Ecosystems ( $J$. Calkins, ed.). Plenum Press, New York, pp. 233-246.

Baker, K.S., R.C. Smith, and A.E.S. Green, 1980. Middle ultraviolet radiation reaching the ocean surface. Photochem. Photobiol. 32(3): 367-374.

Baker, K.S., R.C. Smith and A.E.S. Green, 1982. Middle ultraviolet irradiance at the ocean surface: measurements and models. In, The Role of Solar Ultraviolet Radiation in Marine Ecosystems (J. Calkins, ed.). Plenum Press, New York, pp. 79-91.

Kubitschek, H.E., K.S. Baker and M.J. Peak, 1986. Enhancement of mutagenesis and human skin cancer rates resulting from increased fluences of solar ultraviolet radiation. Photochem. Photobiol. 43: 443-447.

Smith, R.C., 1974. Structure of solar radiation in the upper layers of the sea. In, Optical Aspects of Oceanography, Chapter 5 (J.G. Jerlov, ed.). Academic Press, New York, pp. 95-119.

Smith, R.C. and K.S. Baker, 1979. Penetration of UV-B and biologically effective dose-rates in natural waters. Photochem. Photobiol. 29: 311-323. 
Smith, R.C. and K.S. Baker, 1980. Stratospheric ozone, middle ultraviolet radiation and 14-C measurements of marine productivity. Science 208(444): 592593.

Smith, R.C. and K.S. Baker, 1981. Optical properties of the clearest natural waters (200-800 nm). Applied 0ptics 20: 177-184.

Smith, R.C. and K.S. Baker, 1982. Assessment of the influence of enhanced UV-B on marine primary productivity. In, The Role of Solar Ultraviolet in Marine Ecosystems (J.Caikins, ed.). Plenum Press, New York, pp. 509-537.

Smith, R.C., K.S. Baker, 0. Holm-Hansen, and R. 01 son, 1980. Photoinhibition of photosynthesis and middle ultraviolet radiation in natural waters. Photochem. Photobio1. 31(6): 585-592.

Smith, R.C. and J. Calkins, 1976. The use of the Robertson meter to measure the penetration of solar middle ultraviolet radiation (UV-B) into natural waters. Limnol. Oceanogr. 21: 746-769.

Smith, R.C., R.L. Ensminger, R.W. Austin, J.D. Bailey and

G.D. Edwards, 1979. Ultraviolet submersible spectroradiometer. Proc. of the SPIE Ocean Optics VI 208: 127-140.

Smith, R.C. and J.E. Tyler, 1976. Transmission of solar radiation into natural waters. In, Photochemical and Photobiological Reviews Vol. 1 (K.C. Smith, ed.). Plenum Press, New York, pp. 117-155. 


\title{
UV EFFECTS ON MARINE ORGANISMS
}

\author{
JOHN T. HARDY \\ Department of General Science \\ Oregon State University \\ Weniger Hall 355 \\ Corvallis, Oregon 97331-6505
}

\begin{abstract}
The marine environment covers $71 \%$ of the Earth's surface and is important in the global cycling of carbon as well as many other elements. Also, marine fisheries supply a major part of the diet for much of the world's population. Stratospheric ozone depletion, especially at levels now occurring during springtime over Antarctica, poses a real threat to important biogeochemical cycles and biotic resources in the marine environment.
\end{abstract}

U1traviolet-B radiation (UV-B) penetrates to about $10 \%$ of the euphotic zone. In pelagic ocean water this may exceed 20 meters in depth. Research has demonstrated that enhanced UV-B radiation exposures, simulating realistic future ozone depletions, can produce a number of detrimental effects on marine organisms or communities. Responses include reductions in the growth and photosynthes is of photoautotrophs (phytoplankton and seagrass), acute mortality, and reduced fecundity in copepods, increased abnormalities in shellfish larvae, decreased survival in shrimp and crab larvae, and inhibition of growth and induced lesions in fish Tarvae.

Despite the evident sensitivity of marine organisms to UV-B radiation, great uncertainty remains in extrapolating from effects on individuals to those on the population or community. These uncertainties arise from: 1) the difficulty in defining the in situ exposure regime; 2) the presence of compensatory mechanisms in the population; and 3 ) the occurrence of indirect (food web) effects. Given this uncertainty, an overall assessment of the ecological effects of increasing UV-B radiation in the marine environment is not currently possible. Doseresponse data is needed on the effects of UV-B radiation on plankton, biogeochemial cycles, fish eggs and larvae, corals, and on mixed community mesocosms. In many cases, basic habitat and population distribution data will be needed to build predictive models.

\section{REFERENCES:}

Calkins, J., 1982. Some considerations on the ecological and evolutionary effects of solar UV. In, The Role of Solar Ultraviolet Radiation in Marine Ecosystems (J. Calkins, ed.). Plenum Press, New York, pp. 685-689.

Worrest, R.C., 1982. Review of literature concerning the impact of UV-B radiation upon marine organisms. In, The Role of Solar U1traviolet Radiation in Marine Ecosystems (J. Calkins, ed.). Plenum Press, New York, pp. 429-457.

Worrest, R.C. 1986. The effects of solar UV-B radiation on aquatic systems: an overview. In, Effects of Changes in Stratospheric Ozone and Global Climate Vol. 1: Overview (J.G. Titus, ed.). Environmental protection Agency and United Nations Environment Programme, pp. 175-191. 


\title{
UV-ABSORBING COMPOUNDS
}

\author{
BRUCE E. CHALKER \\ Australian Institute of Marine Science \\ P.M.B. No 3 . \\ Townsville 4810 \\ Queensland, Australia
}

\begin{abstract}
Marine algae and invertebrates living in exposed locations on coral reefs are subjected to high levels of solar ultraviolet radiation. Many of these organisms protect their tissues from the deleterious effects of ultraviolet radiation (UV) by synthesizing specific UV-absorbing compounds. In most cases the identities of these compounds are as yet unknown. An exception is the mycosporine-like amino acids which have been identified in a variety of marine algae and invertebrates, including reef-building corals. Reef corals typically contain a suite of these compounds, each of which has an absorption maximum at a wavelength between 310 and $360 \mathrm{~nm}$. The UV absorption spectra for the combined compounds overlap to form a broad-band filter in the UV-B region, and thereby intercept physiologically damaging wavelengths of solar ultraviolet radiation. The effectiveness of the mycosporine-like amino acids has led to their consideration as model compounds from which a variety of synthetic analogues are now being developed for use in personal suncare preparations and protective coatings.
\end{abstract}

Sequestering UV-absorbing compounds is one adaptive strategy which is available to many, but not all, marine algae and invertebrates. Specific UV-absorbing compounds have also been identified in the eggs of some fish. The extent to which this UV photoadaptation might ameliorate the potential damage caused by increasing solar ultraviolet radiation in the Antarctic is completely unknown. It follows that researchers wishing to assess the biological impact of increased solar ultraviolet radiation should screen their experimental organisms for the presence of these compounds, and determine the types and quantities of compounds when they are indicated. Ecologically appropriate time for photoadaptation prior to exposing organisms to abnormally high levels of UV radiation should also be provided.

\section{REFERENCES}

Dunlap, W.C., and B.E. Chalker, 1986. Identification and quantitation of near-UV absorbing compounds $(S-320)$ in a hermatypic scleratinian. Coral Reefs 5: 155159.

Dunlap, W.C., B.E. Chalker and J.K. 01iver, 1986. Bathymetric adaptation of reef-building corals at Davies Reef, Great Barrier Reef, Australia. III. UV-B absorbing compounds. J. Exp. Mar. Biol. Ecol. 104: 239-248.

Hirata, Y., D. Uemura. K. Ueda and S. Takano, 1979. Several compounds from Palythoa tuberculosa (Coelenterata). Pure and Applied Chem. 51: 1875-1883.

Jokiel, P.L., 1980. Solar ultraviolet radiation and coral reef epifauna. Science 207: 1069-1071. 
Jokiel, P.L., and R.H. York, Jr., 1982. Solar Ultraviolet photobiology of the reef coral Pacillopora damicornis and symbiotic zooxanthellae. Bull. Mar. Sci. 32: $301-315$.

Leach, C.M., 1965. U1traviolet-absorbing substances associated with lightinduced sporulation in fungi. Can J. Bot. 43: 185-200.

Nakamura, H., J. Kobiashi and Y. Hirata, 1982. Separation of mycosporine-like amino acids in marine organisms using reversed-phase high-performance liquid chromatography. J. Chromatogr. 250: 113-118.

Shibata, K., 1969. Pigments and a UV-absorbing substance in corals and bluegreen alga living in the Great Barrier Reef. Plant Cell Physiol. 10: 325-335.

Siebeck, 0., 1981. Photoreactivation and depth-dependent UV tolerance in reef coral in the Great Barrier Reef, Australia. Naturwissenschaften 68: 426-428.

Sutherland, C.S. and K.P. Griffin, 1984. P-aminobenzoic acid can sensitize the formation of pyrimidine dimers in DNA: direct chemical evidence. Photochem. Photobiol. 40: 391-394. 


\title{
UV EFFECTS ON EYES
}

\author{
HUGH R. TAYLOR \\ The Wilmer Institute \\ Johns Hopkins Hospital \\ 600 Wolfe St. \\ Baltimore, MD 21205
}

ABSTRACT: To investigate the association between exposure to ultraviolet (UV) radiation and cataract, we undertook an epidemiologic survey of cataract among 838 watermen who work on the Chesapeake Bay. Their individual ocular exposure was calculated for each year of 1 ife over the age of 16 by combining a detailed occupational history with laboratory and field measurements. Cataracts were clinically graded by both type and severity. Those people with cortical lens opacities had a $21 \%$ higher UV-B exposure at each year of 1 ife, and a UV-B exposure above the median increased the risk of cortical cataract by over threefold. No association was found between nuclear lens opacities and UV-B exposure. Neither cortical nor nuclear opacities were associated with UV-A exposure. Simple measures such as wearing a hat or spectacles protect the eye and could potentially reduce the amount of cortical cataract attributed to UV-B exposure.

\section{REFERENCES:}

Cameron, L.L., 1985. Association of senile lens and dermal changes with cumulative uitraviolet exposure. Ph.D Dissertation. The Johns Hopkins University, Baltimore, Maryland, $292 \mathrm{pp}$.

Hiller, R., R.D. Sperduto and F. Ederer, 1983. Epidemiologic associations with cataract in the 1971-72 national health and nutrition examination survey. Am. J. Epidemio1. 118: 239-249.

Hiller, R., R.D. Sperduto and F. Ederer, 1986. Epidemiologic associations with nuclear, cortical, and posterior subcapsular cataracts. Am. J. Epidemiol. 124: 916-925.

Hollows, F. and D. Moran, 1981. Cataract--the ultraviolet risk factor. Lancet 2: $1249-1250$.

Rosenthal, F.S., A.E. Bakalian, C. Phoon, S. West and H.R. Taylor, 1987. Senile eye changes: determination of ocular exposure to ultraviolet light. Invest. Ophthalmol. Vis. Sci. 28 (suppl): 397.

Rosenthal, F.S., A.E. Bakalian and H.R. Taylor, 1986. The effect of prescription eyewear on ocular exposure to ultraviolet radiation. Am. J. Public Health 76: 1216-1220.

Rosenthal, F.S., C. Phoon, A.E. Bakalian, and H.R. Taylor, 1988. The ocular dose of ultraviolet radiation to outdoor workers. Invest. Ophthalmol. Vis. Sci. 29: 649-656. 
Rosenthal, F.S., M. Safran and H.R. Taylor, 1985. The ocular dose of ultraviolet radiation from sunlight exposure. Photochem. Photobiol. 42: 163-171.

Taylor, H.R., 1980. The environment and the 1ens. Br. J. Ophthalmol. 64: 303310

West, S., F.S. Rosenthal, E.A. Emmett, H. Abbey, B. Munoz and H.R. Taylor, 1987. Senile eye changes: ultraviolet 1 ight and risks of cataract. Invest. Ophthalmol. Vis. Sci. 28(suppl): 397.

Zigman, S., M. Datiles and E. Torczynski, 1979. Sunlight and human cataracts. Invest. Ophthalmol. Vis. Sci. 18: 462-467. 


\title{
UV EFFECTS ON HUMAN HEALTH
}

\author{
MARGARET L. KRIPKE \\ Department of Immunology \\ The University of Texas \\ M.D. Anderson Cancer Center \\ 1515 Holcombe Boulevard \\ Houston, Texas 77030
}

ABSTRACT: The major consequence of stratospheric ozone depletion is to increase the amount of UV-B (280-320 nm) radiation in sunlight reaching the earth's surface. There is considerable evidence that repeated exposure of light-skinned individuals to the UV-B radiation in sunlight leads to the development of basal and squamous cell cancers of the skin. Around 500,000 new cases of skin cancer are diagnosed each year in the United States, making this the most common type of cancer in the United States. The majority of these cancers are thought to be caused by UV-B exposure. Thus an increase in the amount of UV-B radiation in sunlight would further increase the incidence of these skin cancers, which are associated with a low level of mortality (between 1 and $2 \%$ ) but significant morbidity.

There is growing indirect evidence that UV-B radiation also contributes to the incidence of cutaneous melanoma. This cancer of the pigment cells in skin is much less common than the other forms of skin cancer (approximately 25,000 new cases per year in the United States), but causes 1ethal disease in around $25 \%$ of persons affected. The role played by UV-B radiation in the incidence of cutaneous melanoma is not well understood, and it is clear that factors other than sunlight exposure are also involved. Because UV-B radiation is thought to contribute to the development of at least some cutaneous melanomas, an increase in the UV-B radiation in sunlight is expected to increase the incidence of these cancers as well.

Other effects of UV-B radiation on human health include ocular changes leading to the formation of cataracts and other abnormalities and perturbations of the immune system. Studies on laboratory animals have shown that exposure to UV-B radiation interferes with several immune responses, including those directed against skin cancers.

Exposing animals to low doses of UV-B radiation interferes with the function of immune cells in the skin, leading to a decreased immune response, and exposure to higher doses of UV-B impairs certain immune responses occurring at distant, unexposed sites. Evidence for similar immunologic changes in humans is growing, which raises the question of whether exposure to an increased amount of UV-B radiation might interfere with the body's immune defenses against certain infectious diseases. This possibility is currently under investigation in several laboratories using various animal models of infectious diseases.

\section{REFERENCES:}

Hoffman, J.S., 1987. Assessing the Risks of Trace Gases That Can Modify the Stratosphere, Vol. 1: Executive Summary. United States Environmental Protection 
Agency, $92 \mathrm{pp}$.

Kripke, M.L., 1984. Immunologic unresponsiveness induced by ultraviolet radiation. Immunol. Rev. 80: 87-102.

Kripke, M.L., 1988. Impact of ozone depletion on skin cancers. J. Dermatol. Surg. Oncol. In press. 


\title{
TOTAL OZONE CHANGES OVER THE ANTARCTIC CONTINENT AND SOUTHERN OCEAN
}

\author{
ARLIN J. KRUEGER \\ Laboratory for Atmospheres \\ NASA-Goddard Space Flight Center \\ Greenbelt, MD 20771
}

ABSTRACT: Data from the Nimbus 7 Total Ozone Mapping Spectrometer (TOMS) are used to measure the change in total ozone over the Antarctic region. During September and October in recent years a pronounced minimum in total ozone has formed over the Antarctic. This minimum, known as the "ozone hole", is a nearly pole centered feature which has deepened and expanded since 1982. Global record low amounts were first found in 1983; these records were broken in 1985 and 1987. The area of ozone hole was larger that the Antarctic continent in the later years.

Surface fluxes of UV sunlight will increase as the total ozone decreases but the magnitude of the increase depends on the solar zenith angle. Ozone changes late in spring thus have a much larger effect than those taking place in late winter. The average amount of ozone decrease has been computed in October, November, and December using the respective monthly average for the four year period from 1979 to 1982 as a reference. During October 1987 the greatest decrease was 140 Dobson units (DU) over the Ross Sea; total ozone over the entire continent decreased by more than $100 \mathrm{DU}$ and changes greater then 50 DU were present over the entire region south of $60 \mathrm{~S}$. The November 1987 decreases were similar to the October decreases in amplitude; the maximum decreases was 140 DU over the coast of Marie Byrd Land centered on $135 \mathrm{E}$ Tongitude. By December 1987 the Targer decreases had dissipated, although nearly the entire southern hemisphere exhibited ozone losses greater than $20 \mathrm{DU}$; the 1 argest decrease was 60 DU over the Weddell Sea.

\section{REFERENCES:}

Krueger, A.J., P.E. Ardanuy, F.S. Sechrist, L.M. Penn, D.E. Larko, S.D. Doiron, and R.N. Galimore, 1988. The 1987 Airborne Antarctic Ozone Experiment: The Nimbus 7 TOMS Data Atlas. NASA Ref. Publ. 1201 (March 1988), 245 pp.

Krueger, A.J., M.R. Schoeberl and R.S. Stolarski, 1987. TOMS observations of total ozone in the 1986 Antarctic spring. Geophys. Res. Lett. 15: 527-530.

Stolarski, R.S., A.J. Krueger, M.R. SchoeberT, R.D. McPeters, P.A. Newman, and J.C. Alpert, 1986. Nimbus -7 SBUV/TOMS measurements of the spring time Antarctic ozone hole. Nature 322: 808-811. 


\title{
ALEX E.S. GREEN
}

\author{
ICAAS-SSRB
}

University of Florida

Gainsville, FL 32611

\begin{abstract}
*Abstract taken from Green, A.E.S., 1983. The penetration of ultraviolet radiation to the ground. Physiol. Plant. 58: 351-359.
\end{abstract}

ABSTRACT: The evolution of analytic formulas for characterizing the ultraviolet spectral irradiance penetrating to the ground is briefly described. Analytic spectral functions for the extraterrestrial solar spectral irradiance, the ozone absorption coefficients, Rayleigh scattering coefficients and aerosol scattering and absorption coefficients, which are used as basic inputs, are given. With Beer's law, these give immediately the direct solar spectral irradiance. A ratio technique described in quantitative detail gives a procedure for calculating the skylight component of the UV radiation reaching the ground. The influence of ground reflectivity, clouds and a possible connection between photobiology and radiological physics are discussed. Finally the advantages of multiwavelength monitoring are described, using monochromators similar to those used in satellite ozone sounding to serve the needs of the photobiology and the atmospheric science communities.

\section{REFERENCES :}

Bjorn, L.0. and T.M. Murphy, 1985. Computer calculation of solar ultraviolet radiation at ground leve1. Physiol. Veq. 23(5): 555-561.

Dave, J.V. and P. Ha7pern, 1976. Effect of changes in ozone amount on the ultraviolet radiation received at sea level of a model atmosphere. Atmos. Environ. 10: 547-555.

Green, A.E.S., 1966. The Middle Ultraviolet: Its Science and Technology. Wiley, New York, $371 \mathrm{pp}$.

Green, A.E.S., 1983. The penetration of ultraviolet radiation to the ground. Physiol. Plant. 58: 351-359.

Green, A.E.S., K.R. Cross and L.A. Smith, 1980. Improved analytic characterization of ultraviolet skylight. Photochem. Photobiol. 31: 59-65.

Green, A.E.S., T. Sawada and E.P. Shettle, 1974. The middle ultraviolet reaching the ground. Photochem. Photobiol. 19: 251-259.

Nack, M.L. and A.E.S. Green, 1974. Influence of clouds, haze, and smog on the middle ultraviolet reaching the ground. Appl. Opt. 13: 2405-2415.

Schippnick, P.F. and A.E.S. Green, 1982. Analytical characterization of spectral actinic flux and spectral irradiance in the middle ultraviolet. Photochem. Photobiol. 35: 89-101. 
Shettle, E.P. and A.E.S. Green, 1974. Multiple scattering calculation of the middle ultraviolet reaching the ground. App1. Opt. 13: 1567-1581.

Spinhirne, J.D. and A.E.S. Green, 1978. Calculation of the relative influence of cloud layers on received ultraviolet and integrated solar radiation. Atmos. Environ. 12: 2449-2455. 


\section{BIOLOGICALLY RELEVANT UV RADIATION OVER ANTARCTICA \\ JOHN E. FREDERICK \\ Dept. Geophysical Sciences \\ University of Chicago \\ 5734 S. Ellis Ave. \\ Chicago, IL 60637}

ABSTRACT: Ozone measurements from the Nimbus 7 satellite during September and October 1987 allowed estimates of the time history of biologically effective radiation during the most recent "Antarctic ozone hole". Results show that noontime biologically effective radiation levels over McMurdo in early October reached levels similar to those characteristic of the December 21 solstice with an unperturbed ozone amount. This is approximately a factor of 3 above radiation levels typical of early October. Despite these large enhancements, the radiation levels remain less than those normally found at low-to-middle latitudes.

\section{REFERENCES:}

Frederick, J.E., and D. Lubin, 1988. The budget of biologically active ultraviolet radiation in the Earth-atmosphere system. J. Geophys. Res. 93: 38253832 .

Frederick, J.E., 1986. The ultraviolet radiation environment of the biosphere. In, Effects of changes in Stratospheric Ozone and Global Climate, Volume I: Overview (J.G. Titus, ed.). Environmental Protection Agency, Washington, D.C., pp. 121-128.

Frederick, J.E. and H.E. Snell, 1988. Ultraviolet radiation levels during the Antarctic Spring. Science 241: 438-440.

Lubin, D., J.E. Frederick and A.J. Krueger, 198?. The ultraviolet radiation environment of Antarctica: McMurdo Station during September-October 1987. J. Geophys. Res., submitted (1988). 


\title{
SPECIFICATIONS OF THE UNITED STATES ANTARCTIC PROGRAM'S EQUIPMENT SYSTEM FOR MONITORING UV RADIATION
}

\author{
GARY W. HARRIS \\ Research Instrument Systems \\ 5356 S. El Camino Dr. \\ Tempe, AZ 85283
}

The versatile, laboratory-based equipment system developed for the United States Antarctic Program incorporates a scanning spectroradiometer and is designed for high sensitivity and long-term stability under conditions of continuous use. The system can be set to take data, intensity-calibration and wavelength-calibration scans at preprogrammed times during a 24-hour period. The system can then operate unattended until disc space on the controliing computer is filled. As presently configured, the system meets the following specifications:

MONOCHROMETER TYPE: Double $0.1 \mathrm{~m}$; holographic gratings; $250-\mathrm{nm}$ blaze

STRAY LIGHT: $2 \times 10^{-9}$ at 8 bandwidths from $632.8-\mathrm{nm}$ laser 1 ine

WAVELENGTH RANGE: $250-650 \mathrm{~nm}$

WAVELENGTH RESOLUTION: $0.05 \mathrm{~nm} / \mathrm{step}$

WAVELENGTH RESOLUTION: $0.05 \mathrm{~nm} / \mathrm{step}$

WAVELENGTH ACCURACY: $+/-0.5 \mathrm{~nm}$

WAVELENGTH PRECISION: $+/-0.2 \mathrm{~nm}$

BANDWIDTH: $1.1 \mathrm{~nm}$ with $0.167-\mathrm{nm}$ slits supplied

ENTRANCE OPTICS: Integrating sphere with integral wavelength and intensity calibration sources. When mounted into a roofbox, it includes a shutter mechanism, and quartz dome to seal out moisture. Entrance optics may be updated in the future. A tefion diffuser assembly is presently being evaluated to reduce distortions caused by the quartz dome.

SCAN SPEED: $0.02-25 \mathrm{~nm} / \mathrm{sec}$; computer controlled

DETECTOR: Photomultiplier tube in shielded, cooled housing

AMPLIFIER SENSITIVITY: $10^{-12}-10^{-4}$ amps.

DYNAMIC RANGE: $10^{-6}$

INTEGRATION TIME: $0.001-64 \mathrm{sec}$; computer controlled

HIGH VOLTAGE: 0 - 2000 volts; computer controlled

PHOTON COUNTING: $10^{7}$ counts/sec maximum; count integration time $0.001-64$ sec; computer controlled 
NOISE AT $300 \mathrm{NM:}$ Typically $10^{-9}-2 \times 10^{-10} \mathrm{~W} / \mathrm{cm}^{2} / \mathrm{nm}$ in current mode with $0.5-\mathrm{sec}$ integration time

CALIBRATION SYSTEM: Internal wavelength and intensity mounted on integrating sphere; external $200-W$ standard lamp mounted on jig

COMPUTER SYSTEM: IBM-compatible portable with two $1.4 \mathrm{Mb}$ minifloppy drives; larger unit is being considered

COMPUTER SOFTWARE: Menu-driven package which allows scheduling any number of scans at different times during the day for unattended operation. Scans may include automatic intensity- or wavelength-calibration runs. Scans may be broken up into any number of segments with different sensitivities, wavelength increments, etc. for each segment. All data is stored in binary form. A separate program will print, graph, or convert to ASCII format the raw data for use in data-base programs. 


\title{
COLLECTION AND DISTRIBUTION OF DATA FROM \\ THE UNITED STATES ANTARCTIC PROGRAM'S UV MONITORING NETWORK
}

\author{
C. ROCKY BOOTH \\ Biospherical Instruments, Inc. \\ 4901 Morena Blvd. Suite 1003 \\ San Diego, CA 92117 \\ C. SUSAN WEILER \\ POLLY A. PENHALE \\ Division of Polar Programs \\ National Science Foundation \\ 1800 G St. NW \\ Washington, D.C. 20550
}

Ozone levels over the Antarctic continent have decreased dramatically over the past decade; while it is known that decreases in total ozone will increase the amount of UV-B radiation reaching the earth's surface, models have not yet been developed that can accurately predict ultraviolet radiation levels at the earth's surface for high latitudes. In order to obtain direct measurements of predicted changes in UV-B levels resulting from the Antarctic "ozone hole", the United States Antarctic Program (USAP) is developing a network for monitoring ultraviolet radiation. Equipment systems have been installed at the three Antarctic locations, and a system is planned for installation at Ushuaia, Argentina. The network, which will span 35 degrees of latitude, was chosen to include stations located within and outside the "ozone hole" region:

AMUNDSEN-SCOTT SOUTH POLE STATION

MC MURDO STATION

PALMER STATION

USHUAIA, ARGENTINA

$$
\begin{array}{llllll}
90^{\circ} & & S & & & \\
77^{\circ} & 51 & \text { S } & 166^{\circ} & 40 & \text { E } \\
64^{\circ} & 46 & \text { S } & 64^{\circ} & 03^{\prime}, W \\
54^{\circ} & 49^{\prime} & \text { S } & 68^{\circ} & 19 & \text { W. }
\end{array}
$$

The USAP's UV monitoring network will be coordinated through C.R. Booth. The equipment is scheduled for operation throughout the austral spring, summer and autumn to document changes in UV-B resulting from seasonal changes in ozone concentration. The final sampling schedule has not yet been established; tentative $\mathrm{plans}$ are as follows:

DATA COLLECTION: The preliminary sampling schedule is planned to include hourly scans during daylight hours at three levels of sensitivity:

SENSITIVITY

$$
\begin{aligned}
& \text { high } \\
& \text { medium } \\
& \text { low }
\end{aligned}
$$

\section{WAVELENGTH RANGE}

$$
\begin{aligned}
& 280-315 \mathrm{~nm} \\
& 280-350 \mathrm{~nm} \\
& 280-700 \mathrm{~nm}
\end{aligned}
$$

STEP SIZE

$0.2 \mathrm{~nm}$

$0.5 \mathrm{~nm}$

$5.0 \mathrm{~nm}$

Calibration scans for wavelength and intensity will be taken daily. The spectroradiometers will be interfaced with Eppley UV radiometers (290-385 nm) and Eppley spectral radiometers $(300-3000 \mathrm{~nm})$ to account for transient changes in cloud cover which may occur during the time it takes to complete spectroradiometer scans (ca. $10 \mathrm{~min} . / \mathrm{scan}$ ). 
DATA PROCESSING: Data from all systems will be transmitted to Biospherical Instruments, Inc. where it will be processed to three levels:

RAW DATA: Raw data will be archived after its transmission from the remote sites. The data will be verified and scan parameters (start wavelength, stop wavelength, and high-voltage and tube currents) will be specified.

PRELIMINARY DATA: Data from each hourly scan will be processed with calibration constants applied to provide information in approximately the following forms:

$$
\begin{aligned}
& 280-350 \mathrm{~nm} \text { averaged over } 1-\mathrm{nm} \text { increments } \\
& 280-700 \mathrm{~nm} \text { averaged over } 5-\mathrm{nm} \text { increments } \\
& \text { UV-B, UV-A, and PAR averaged hourly } \\
& \text { Weighted observations using various action spectra }
\end{aligned}
$$

FINAL DATA: Data will be corrected annually, after each site has been visited for an appraisal of the system's calibration stability.

DATA DISTRIBUTION: Those interested in obtaining data should contact P.A. Penhale. 


\section{PARTICIPANT LIST}

\section{WORKSHOP, UV RADIATION AND BIOLOGICAL RESEARCH IN ANTARCTICA}

PARTICIPANT LIST

BAKER, Dr. KAREN S.

IMR A-018, University of California at San Diego, La Jolla, CA 92093

BIDIGARE, Dr. ROBERT R.

Texas A \& M Research Foundation, Box 3578, College Station, TX 77843

BOOTH, Mr. C. ROCKY

Biospherical Instruments Inc., 4901 Morena Blvd. Suite 1003,

San Diego, CA 92117

BOVERIS, Dr. ALBERTO

School of Biochemistry, University of Buenos Aires, Buenos Aires, Argentina

BRUECKNER, Dr. GUNTHER

4160 Naval Research Laboratory, Washington, D.C. 20375-5000

CALDWELL, Dr. MARTYN M.

Dept. Range Science, Utah State University, Logan, UT 84322

CHALKER, Dr. BRUCE E.

Australian Institute of Marine Sciences, PMB No. 3, Townsville 4810, Queensland, Australia

CLARK, Dr. DENNIS

National Oceanic and Atmospheric Administration, NESDIS, SPC Mail Stop L, Washington, D.C. 20233

COOHILL, Dr. THOMAS

Dept. Physics, Western Kentucky University, Bowling Green, KY 42101

CULLEN, Dr. JOHN J.

Bigelow Laboratory for Ocean Sciences, Mckown Point, West Boothbay Harbor, ME 04575

DeFABO, Dr. EDWARD C.

Ross Hall Room 101-B, George Washington University Medical Center, 2300 I St. N.W., Washington, D.C. 20037

DeLACA, Dr. TED. E.

Division of Polar Programs, National Science Foundation, 1800 G St. N.W., Washington, D.C. 20550

DeLUISI, Dr. JOHN J.

National Oceanic and Atmospheric Administration, ERL-ARL-GMCC R329, B1dg. RB3 Room 325, Boulder, CO 80303 
EL-SAYED, Dr. SAYED. Z.

Texas A \& M Research Foundation, Box 3578, College Station, TX 77843

FALKOWSKI, Dr. PAUL G.

Oceanographic Science Division, Brookhaven National Observatory, Upton, NY 11973

FORBES, Dr. DONALD

School of Medicine, Temple University, 3322 N. Broad St., Philadelphia, PA 19140

FREDERICK, Dr. JOHN E.

Dept. Geophysical Sciences, University of Chicago, 5734 S. Ellis Ave., Chicago, IL 60637

FRIEDMANN, Dr. E. IMRE

Dept. Biological Science, Florida State University, Tallahassee, FL 32306-2043

GREEN, Dr. ALEX E.S.

ICAAS-SSRB, University of Florida, Gainesville, FL 32611

HANSON, Dr. ROGER

Skidaway Institute of Oceanography, University of Georgia, P.0. Box 13687, Savannah, GA 31416

HARDY, Dr. JOHN T.

General Science Dept., Oregon State University, Corvallis, OR 97331

HARRIS, Mr. GARY W.

Research Instrument Systems, 5356 S. El Camino Dr., Tempe, AZ 85283

HOLM-HANSEN, Dr. OSMUND

Polar Research Program A-002, Scripps Institution of Oceanography, University of California at San Diego, La Jolla, CA 92093

KARENTZ, Dr. DENEB

Lab. Radiobiology and Environmental Health, University of California at San

Fransisco, LR-102, 3rd and Parnassus Avenues, San Fransisco, CA 94143

KLEMPERER, Dr. WILLIAM

Dept. Chemistry, Harvard University, 12 0xford St., Cambridge, MA 02138

KRUEGER, Dr. ARLIN J.

Laboratory for Atmospheres, NASA-Goddard Space Flight Center, Greenbelt, MD 20771

KRIPKE, Dr. MARGARET L.

Dept. Immunology, University of Texas, M.D. Anderson Cancer Center, 1515 Holcombe Blvd., HMB 178, Houston, TX 77030

KRIZEK, Dr. DONALD

United States Department of Agriculture, ARS Plant Stress Lab., Room 206 Bldg. 001, BARC-West, Beltsville, MD 20705 
LONGSTRETH, Dr. JANICE D.

ICF-CLEMENT, 9300 Lee Hwy., Fairfax, VA 22031-1207

LUBIN, Mr. DAN

Dept. Geophysical Sciences, University of Chicago, 5801 S. Ellis Ave., Chicago, IL 60637

MCEUEN, Dr. SCOTT

Harbor Branch Institute, 5600 01d Dixie Highway, Fort Pierce, FL 34946

MITCHELL, Dr. B. GREGORY

Polar Research Program, A-002, Scripps Institution of Oceanography, University of California at San Diego, La Jolla, CA 92093

ORCE, Dr. VICENTE LUIS

Radiation Biology, Atomic Energy Commission, Av. Libertador 8250, 1429 Buenos Aires, Argentina

PENHALE, Dr. POLLY A.

Division of Polar Programs, National Science Foundation, 1800 G St. N.W., Washington D.C. 20550

ROBBERECHT, Dr. RONALD

Dept. Range Resources, University of Idaho, Moscow, ID 83843

ROSENTHAL, Dr. FRANK

Dept. Pharmacology, University of Massachusetts Medical School, Worcester, MA 01605

SALAS, Dr. CARLOS

Dept. Chemistry, Faculty of Science, University of Santiago, Santiago, Chile SAUNDERS, Dr. ROBERT

Physics B1dg. Room A-221, Federal Bureau of Standards, Gaithersburg, MD 20899

SCOTTO, Dr. JOSEPH

National Cancer Institute, Landow Bldg. 3C18, Bethesda, MD 20892

SETLOW, Dr. RICHARD B.

Dept. Biology, Brookhaven National Laboratories, Upton, NY 11973

SMITH, Or. RAYMOND C.

Center for Remote Sensing and Environmental Optics, University of California at Santa Barbara, Santa Barbara, CA 93106

STEDMAN, Dr. DONALD H.

University of Denver, University Park, Denver, C0 80208

SULLIVAN, Or. JOSEPH

Dept. Botany, University of Maryland, College Park, MD 20742 
TAGUCHI, Dr. SATORU

Dept. Oceanography, University of Hawai a Manoa, 2540 Maile Way, Honolulu, HI 96822

TAYLOR, Dr. HUGH

Wilmer Institute, Johns Hopkins Hospital, 600 Wolfe St., Baltimore, MD 21205

WEBER, Dr. LARRY H.

Division of International Programs, National Science Foundation, 1800 G. St.

N.W., Washington D.C., 20550

WEILER, Dr. C. SUSAN

Dept. Biology, Whitman College, Walla Walla, WA 99362

WILKNISS, Dr. PETER E.

Division of Polar Programs, National Science Foundation, 1800 G St. N.W., Washington, D.C. 20550

YENTSCH, Dr. CHARLES S.

Bigelow Laboratory for Ocean Sciences, McKown Point, West Boothbay Harbor, ME 04575

YENTSCH, Dr. CLARICE M.

Bigelow Laboratory for Ocean Sciences, McKown Point, West Boothbay Harbor, ME 04575

The National Science Foundation has TDD (Telephonic Device for the Deaf) capability, which enables individuals with hearing impairment to communicate with the Division of Personnel and Management about NSF programs, employment, or general information. This number is (202) 357-7492. 
NATIONAL SCIENCE FOUNDATION

WASHINGTON, D.C. 20550

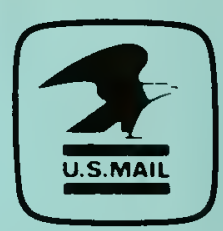

OFFICIAL BUSINESS

PENALTY FOR PRIVATE USE $\$ 300$

POSTAGE AND FEES PAID

RETURN THIS COVER SHEET TO ROOM 233, IF YOU DO NOT WISH TO RECEIVE THIS MATERIAL $\square$, OR IF CHANGE OF ADORESS IS NEEOED INDICATE CHANGE, INCLUDING ZIP CODE ON THE LABEL, (DO NATIONAL SCIENCE FOUNDATION NOT REMOVE LABEL) 